\title{
COPING WITH FEBRILE ILLNESS IN CHILDREN: A QUALITATIVE INTERVIEW STUDY OF PARENTS
}

\author{
Urzula Nora Urbāne $^{1,2, \#}$, Dita Gaidule-Logina1, Dace Gardovska ${ }^{1,2}$, \\ and Jana Pavāre ${ }^{1,2}$

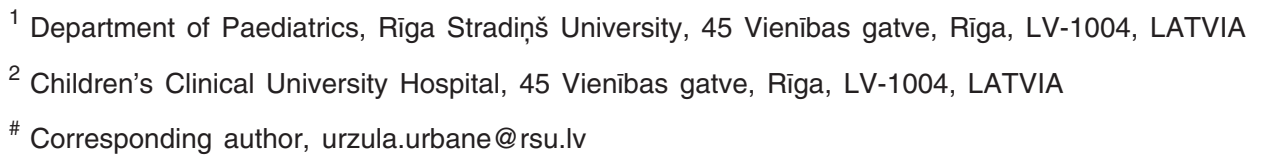

Contributed by Dace Gardovska

The aim of this study was to investigate parental perception of febrile illness in their children, the most commonly applied management practices, as well as the expectations from clinicians when coping with fever in children. The study included parents of patients admitted to the Emergency and Observation Department of Children's Clinical University Hospital in Riga, Latvia. Data were collected via semi-structured interviews. All interviews were transcribed, and the transcripts analysed by inductive thematic analysis. Thirty-four parental interviews were analysed. Six themes emerged from the study, which were: signs causing concern; beliefs regarding fever; assessment and monitoring of fever; fever management practices; help-seeking behaviour; and expectations from the healthcare personnel. Many parents believed that fever could potentially cause injuries to the nervous system, kidneys, the brain, other internal organs, and even cause death. The perceived threat of fever resulted in frequent temperature measurements and administration of antipyretics. Meeting the emotional and information needs of the parents were considered as equally important to meeting the child's medical needs. The study found that fever phobia exists among parents. Parental misconceptions of fever lead to overly zealous management practices. Parental education initiatives must be organised in order to improve parental knowledge of fever and its management in children.

Key words: fever in children, parental concern, fever phobia.

\section{INTRODUCTION}

Fever in children is one of the most common reasons for seeking medical attention. Reports from developed countries state that almost $40 \%$ of children younger than 6 months, and $60 \%$ of children aged 6 months to 5 years have had a febrile episode (Hay et al., 2005). In most cases, the cause of fever is self-limiting viral infections; only $1 \%$ of febrile children presenting to primary care, and 4 to $25 \%$ of those presenting to Emergency Departments, are diagnosed with serious bacterial infections (SBI) (Van den Bruel et al.., 2010; Nijman et al., 2013).

Fever occurs as a result of the increase in the hypothalamic set point, which is a regulated process triggered by pyrogenic ubstances, either microbial products or cytokines secreted by the host during inflammatory response
(Mackowiak, 1998; Aronoff et al., 2001). There is evidence that elevated body temperature aids the host in cases of infection by increasing chemotactic attraction of neutrophils to the affected site (Roberts Jr, 1991), amplifying IFN activity (Heron et al., 1978; Ron et al., 1984), and by increasing stress responses in microbes (Srivastava, 2002). Furthermore, administration of antipyretics in cases of fever can repress the hosts immune response by reducing immune cell adherence to endothelium, suppressing leukocyte migration, and inhibiting cytokine production (Aronoff et al., 2001).

As it is a physiologically regulated process, fever rarely rises above potentially lethal levels of $42{ }^{\circ} \mathrm{C}$ (Caspe et al., 1989). Fever must be distinguished from hyperthermia, an uncontrolled increase in the body temperature despite a normal hypothalamic set point, which occurs if exposure to ex- 
ternal heat or internal production of heat exceeds the body's cooling ability, and could result in detrimental consequences (Goodman et al., 1991; Simon, 1993).

Several guidelines for effective and evidence-based evaluation and management of fever have been created for clinicians, with the British National Institute for Health and Care Excellence (NICE) guidelines being the most widely applied in Europe (Davis, 2013). The guidelines clearly present information on appropriate measuring of fever, thorough assessment of the child and recognising serious illness, and guidance on antipyretic intervention, and a section is dedicated to presenting this information in a way that is easy to understand for the parents (Davis, 2013).

And yet the dominating perceptions and beliefs of parents on how to manage fever in their children often differ significantly from the information provided by evidence-based guidelines. Studies show that parents often misinterpret their child's body temperature and fever (Singhi et al., 1991; Blumenthal, 1998), and often use antipyretics inappropriately (Al-Eissa et al.., 2000; McErlean et al., 2001). Also, fever is raising unrealistic and unfounded concerns with regards to the harmful effects it could potentially have on the child. The term "fever phobia" was first used in a study by Schmitt and colleagues published in 1980, where in a survey $94 \%$ of parents showed beliefs that fever could cause serious side effects such as cerebral damage, convulsions, coma, blindness, and even death (Schmitt, 1980). Decades later, it is evident from other studies that these beliefs still persist, along with overly zealous and potentially harmful fever home management practices (Crocetti et al., 2001; Poirier et al., 2010).

With such a gap between the evidence-based treatment strategies proposed by clinicians and existing parental practices of managing fever in their children, it is necessary to investigate the objectives behind the beliefs and reasoning of the parents and carers. It has been previously described that perceived threat to the child's health and sense of responsibility to protect their child from it (Kai, 1996b), as well as insufficient attention paid by physicians to their concerns and information needs (Kai, 1996a) create parental insecurity and frustration in communication with clinicians. The aim of this study was to investigate parental perception of febrile illness in their children, the most commonly applied management practices, as well as the expectations from clinicians when coping with fever in children.

\section{METHODS}

Design. The experiences of parents in dealing with a febrile illness in their children were explored by a phenomenological approach. Phenomenology involves the use of detailed description and close analysis of experience lived by the people who have experienced the phenomenon, setting aside the biases and preconceived assumptions about them
(Starks et al., 2007; Creswell, 2018). In this qualitative study, a convenience sample of parents or carers of children with febrile illness was recruited from the patients admitted to the Emergency and Observation Department of Children's Clinical University Hospital in Riga, Latvia. Recruitment was finalised when the data saturation had been reached, that is, when no new information emerged from the interviews (Francis et al., 2010). Information on the parental age and education level, and number of children in the family was also collected. Informed consent to participation in the study was obtained from all participants. Ethics approval granted by Rīga Stradiņš University was obtained prior to the study.

Data collection and analysis. The experiences and beliefs of parents were assessed via semi-structured qualitative interviews. The topic guide for the interviews, was developed based on rigorous study of existing literature as well as professional opinions. Before the study, the interviews were piloted by two parents, who suggested no major corrections. The questions asked during the interview are displayed in Table A in the supplementary material available on the online version*. The topics discussed in the interview included:

1) signs and symptoms causing increasing concern;

2) ways of assessing and monitoring fever;

3) opinion and beliefs on the positive effects of fever;

4) opinion and beliefs on the possible side effects and dangers of fever;

5) practices of management of fever;

6) seeking for help in case of fever in their child;

7) expectations from healthcare professionals when dealing with febrile illness in their child;

8) experience in communication with doctors regarding febrile illness in their child.

Interviews took place between October 2017 and April 2018. The study population was selected from the participants of another study, "Diagnostic value of clinical presentation, parental concern and clinicians' gut feeling in identifying serious bacterial infections in febrile children", including the parents who agreed to the additional interview. This study was a part of the State Research Programme "Biomedicine", Project No. 5.6.2. From the studied population, parents who provided informed consent for the interviews with audio recording were enrolled in the qualitative study. Parents from different educational backgrounds, as well as with varying number of children, were selected. Parents provided informed consent for the interview upon enrolment at the emergency department, where most of the interviews took place. However, some interviews were postponed to a later time within 72 hours of ad-

\footnotetext{
* http://www.lza.lv/images/stories/Section_B/Urbane_Supplementary_material.pdf
} 
mission, after their children had received immediate help and were in a stable condition, and when the psychological condition of the parents allowed participation in the interview.

Before the interview, the parents were asked to complete a short questionnaire assessing their age, education level, and number of children in the family. Prior experience with febrile episodes, hospitalisation and serious bacterial infections in their children was also noted. All interviews were recorded and transcribed for analysis. Participants were not asked to verify their transcripts.

Inductive thematic analysis was used to analyse the data of all transcripts (Braun and Clarke, 2006). Key themes were identified through a step-by-step process, including: (a) familiarisation with all data through repeated listening to the records and reading of the transcripts; (b) descriptive coding of repeated patterns and themes; (c) linking, grouping, and categorisation of the themes and subthemes.

\section{RESULTS}

Participants. Data saturation for the study was reached after 30 interviews and confirmed after the next four interviews. The duration of the interview was between 5 minutes and 19 seconds to 22 minutes and 5 seconds, the median duration was 10 minutes. In total, the parents of 34 patients were enrolled, among them were twenty-nine mothers, three fathers, one grandmother, and in one case both father and mother participated in the interview. The age of the participants ranged from 22 to 63, the median age was 34 years. Twelve participants were parents of an only child, eighteen had two children in the family, and four participants had three children. Most of the participants had higher education (either bachelor's or master's degree). The demographic data as well as education level of the participants can be seen in Table B in the supplementary material*. The age of the febrile children with whom the parents had sought help at the Emergency department ranged from two months to fifteen and a half years. The age, gender, time elapsed before seeking help, and the diagnoses of the children are reflected in Table $\mathrm{C}$ in the supplementary material*.

Main themes. Six main themes emerged from the study, which were: signs causing concern; beliefs regarding fever; assessment and monitoring of fever; fever management practices; help-seeking behaviour; and expectations from the healthcare personnel.

Signs causing concern. The main factors that raised anxiety and led to seeking medical help were fever itself, behavioural changes associated with fever, respiratory symptoms, and pain.

The presence of elevated body temperature and fever was emphasised over other symptoms as the main reason for parental concern in one-third of the cases $(n=11)$. This was characteristic to parents of one or multiple children alike, and all but one of these parents had higher education. These
FEVER AS THE CAUSE OF PARENTAL CONCERN

\begin{tabular}{|l|l|}
\hline $\begin{array}{l}\text { Anxiety over inability } \\
\text { to reduce fever }\end{array}$ & $\begin{array}{l}\text { Interview No. 27: "She was shivering (...) The } \\
\text { temperature was just getting higher and higher. } \\
\text { I was already tired, I could not go on keeping } \\
\text { her cool. I understood I would not be able to } \\
\text { handle that for the second night in a row." }\end{array}$ \\
\hline $\begin{array}{l}\text { Anxiety over frequent } \\
\text { elevations in body } \\
\text { temperature }\end{array}$ & $\begin{array}{l}\text { Interview No. 26: "In her case I feel anxious } \\
\text { when her temperature is above } 38^{\circ} \mathrm{C} . \text { If the } \\
\text { temperature reaches that every } 8 \text { hours, I am } \\
\text { very anxious, but if it happens every } 6 \text { hours } \\
\text { then I am panicking." }\end{array}$ \\
\hline $\begin{array}{l}\text { Inexperience with } \\
\text { febrile illness } \\
\text { in a child }\end{array}$ & $\begin{array}{l}\text { Interview No. 18: "This is my first child, his } \\
\text { first illness. The culmination of everything was } \\
\text { when his temperature reached } 38.8 \text { degrees. } \\
\text { That is when I understood that we need to go to } \\
\text { the hospital." }\end{array}$ \\
\hline
\end{tabular}

Table 2

BEHAVIOURAL CHANGES DURING FEVER RAISING PARENTAL CONCERN

\begin{tabular}{|l|l|}
\hline Fatigue, apathy & $\begin{array}{l}\text { Interview No. 7: "He was just lying in bed and } \\
\text { did not want to do anything. He started to com- } \\
\text { plain about feeling very unwell." } \\
\text { Interview No. 12: "She became very tired, did } \\
\text { not want to do anything, started to cry. She was } \\
\text { not active and was drinking less than usual." }\end{array}$ \\
\hline $\begin{array}{l}\text { Loss of interest in } \\
\text { favourite activities }\end{array}$ & $\begin{array}{l}\text { Interview No. 30: "She was lying in bed the } \\
\text { whole time, was not playing. She was unable to } \\
\text { go to bathroom as she was not strong enough. } \\
\text { She didn't want to watch cartoons..." }\end{array}$ \\
\hline Seizure-like activities & $\begin{array}{l}\text { Interview No. 19: "His arm started to shake, } \\
\text { and one of the eyes closed..." } \\
\text { Interview No. 31: "His body was jerking for a } \\
\text { moment, the eyes seemed to roll to the other } \\
\text { side..." }\end{array}$ \\
\hline
\end{tabular}

parents mostly expressed an overwhelming sense of duty to reduce the child's temperature, and expressed anxiety when were not successful (Table 1).

Behavioural changes, such as fatigue, apathy, not getting up from the bed, refusal to drink, loss of interest in favourite activities, excessive crying, were identified as the main cause for concern in about one-third of parents (Table 2). Two parents were alarmed by witnessing seizure-like activities. The parents who emphasised behavioural changes as alarming in most cases had multiple children, but only two of them had higher education.

Some patients got concerned when noticing respiratory symptoms in their febrile child, such as cough, runny nose, rapid breathing, difficulty breathing, "choking", and cyanosis (Table 3 ).

Pain was the most alarming sign noted by six of the participants. The concern of these parents was raised by pain that did not respond to medication, pain that was stronger than in the child's previous experience, and when child had pain in an unusual site (Table 4).

\footnotetext{
* http://www.lza.lv/images/stories/Section_B/Urbane_Supplementary_material.pdf
} 
MOST COMMON RESPIRATORY SIGNS RAISING PARENTAL CONCERN

\begin{tabular}{|l|l|}
\hline Cough, choking & $\begin{array}{l}\text { Interview No. 6: "His nose was very runny, } \\
\text { even from the mouth... He was coughing horri- } \\
\text { bly. I think, when there is cough and high tem- } \\
\text { perature, it means inflammation." } \\
\text { Interview No. 1: "She had an awful cough, I } \\
\text { thought she was choking..." }\end{array}$ \\
\hline Rapid breathing & $\begin{array}{l}\text { Interview No. 25: "...even during sleep, his } \\
\text { heart rate and breathing was changed..." }\end{array}$ \\
\hline $\begin{array}{l}\text { Breathing difficulty, } \\
\text { cyanosis }\end{array}$ & $\begin{array}{l}\text { Interview No. 8: "He was breathing unevenly, } \\
\text { his lips got blue when the temperature got } \\
\text { high." }\end{array}$ \\
\hline
\end{tabular}

Table 4

\section{PAIN AS THE REASON FOR PARENTAL CONCERN}

\begin{tabular}{|l|l|}
\hline $\begin{array}{l}\text { Pain not responding } \\
\text { to medication }\end{array}$ & $\begin{array}{l}\text { Interview No. 34: "My child was screaming } \\
\text { from pain; her tummy was aching. We gave } \\
\text { some medicine, but it didn't get better, it only } \\
\text { got worse." }\end{array}$ \\
\hline $\begin{array}{l}\text { Pain stronger than ever } \\
\text { before }\end{array}$ & $\begin{array}{l}\text { Interview No. 22: "He has had headache before, } \\
\text { but not this strong, and not at just } 37^{\circ} \text { C..." } \\
\text { Interview No. 20: "I thought I could not wait } \\
\text { any longer, her condition seemed very seri- } \\
\text { ous...she did not want to eat, did not want to } \\
\text { drink, she was just complaining that her leg } \\
\text { hurts, with tears in her eyes." }\end{array}$ \\
\hline Pain at an unusual site \\
$\begin{array}{l}\text { Interview No. 30: "My daughter had been com- } \\
\text { plaining about stomach ache for a couple of } \\
\text { days, I thought she had just eaten something } \\
\text { [wrong], and just gave her some medicine. But } \\
\text { a couple of days later she developed high tem- } \\
\text { perature. Her back was aching so that she could } \\
\text { not sit up." }\end{array}$ \\
\hline
\end{tabular}

Other signs that were mentioned by a few parents as the main concerns were sudden swelling of one of the extremities, vomiting, diarrhoea, skin rash, and fever with no apparent cause.

Beliefs regarding fever. The study participants expressed diverse opinions on whether or not fever was protective of or facilitating the progress of the illness. Some parents agreed that fever is helping the organism to fight against the pathogens:

Interview No. 27: "[Fever] is an excellent indicator that the body is fighting, that the immune system is fighting the infection, the virus. The change in body temperature shows if the body can handle the infection on its own, or if help from outside is needed."

However, in most cases the parents believed that fever is beneficial to fighting infection only to some extent:

Interview No. 15: "Elevated temperature is a sign that the organism is fighting the infection, either a virus or something else. But if it is higher than $38{ }^{\circ} \mathrm{C}$, the body cannot deal with it. The organs can't function at such a high temperature, it's just extra work..."

\section{DETRIMENTAL EFFECTS ATTRIBUTED TO FEVER}

\begin{tabular}{|l|l|}
\hline $\begin{array}{l}\text { Injury to the nervous } \\
\text { system }\end{array}$ & $\begin{array}{l}\text { Interview No. 13: “...brain cells die. There can } \\
\text { be seizures, irreversible effects on the body. I } \\
\text { know it is dangerous..." }\end{array}$ \\
\hline Injury to the lungs & $\begin{array}{l}\text { Interview No. 32: "Those little lungs just burn } \\
\text { (...) there is a risk for a stroke...". }\end{array}$ \\
\hline $\begin{array}{l}\text { Various adverse } \\
\text { effects }\end{array}$ & $\begin{array}{l}\text { Interview No. 11: "I don't ever let the tempera- } \\
\text { ture to get above } 38^{\circ} \text { C. I am scared of the com- } \\
\text { plications. High temperature can cause loss of } \\
\text { consciousness, the breathing can stop, there can } \\
\text { be skin rash, diarrhoea, dehydration..." }\end{array}$ \\
\hline Death & $\begin{array}{l}\text { Interview No. 25: "The water disappears. It can } \\
\text { lead to death of the child. I have had experi- } \\
\text { ence, when, wrapped and bundled, the child } \\
\text { just burns. Heart rate and breathing rate in- } \\
\text { creases. Oxygen loss is possible. High tempera- } \\
\text { ture is a side effect of an illness. It fights it } \\
\text { when it is around } 37 \text { to } 38^{\circ} \text { C. When it is higher } \\
\text { than } 42^{\circ} \text { C, the child dies." }\end{array}$ \\
\hline
\end{tabular}

Interview No. 22: “At 37 to $38{ }^{\circ} \mathrm{C}$ the body fights viruses and bacteria. But if it is above $39{ }^{\circ} \mathrm{C}$, the body can't handle it on its own."

In contrast, some other parents believed that fever reduces the ability to fight infection due to dehydration and overheating:

Interview No. 6: "Because of high temperature, the water disappears from the body. Just like when you heat water in a teapot. Then the person urinates less. The less urine, the less microorganisms are excreted from the body. Fever above $38.5^{\circ} \mathrm{C}$ is dangerous."

Interview No. 16: "Immunity rapidly worsens. It is dangerous for the organs, for the brain. They can burn, cease to work. As I understand, it is very dangerous."

People with multiple children, regardless of education level, were slightly less sceptical about fever. However, plenty of harmful effects were attributed to fever by almost all respondents. Along with dehydration and possibility of seizures, it was believed to cause injuries to nervous system, kidneys, the brain, other internal organs, and some parents even believed it could lead to death (Table 5).

These harmful features were attributed to fever by parents of one or multiple children alike, and there were no differences between the beliefs of people with and without higher education.

Assessment and monitoring fever. Most of the participants measured their child's temperature for the first time in a febrile episode whenever the child felt hot to touch. Later, when assessing the child again, most commonly in order to evaluate the effects of antipyretics, the strategies varied.

Around one-third of parents $(n=12)$ went on to reassess the temperature of the child only when they subjectively felt that the child has a high temperature again: 
Interview No. 1: "You can feel everything when you take a child in your lap. Especially if it is a baby. You can feel the fever when the child is hot."

Interview No. 17: "I can already see when the child has a fever. After I gave medication, four hours later my daughter said she was feeling cold. I remeasured the temperature, it was high. My doctor told me to measure the temperature every 4 hours. If I feel the temperature is rising, I measure it, if not, I don't."

Other parents measured their child's temperature according to some sort of schedule. Mostly they reassessed the temperature around one hour after antipyretics, and later according the frequency of re-evaluation varied from once in six hours to once in every 15 minutes.

Interview No. 19: "After giving medication, I measure the temperature every 30 minutes. When the temperature gets lower, I measure every 2 to 3 hours."

Interview No. 14: "At the beginning I measure it every 20 minutes. If the temperature is high, I measure every 10 to 15 minutes the whole day. When it gets lower, I measure it every hour."

The frequency of reassessing the body temperature of the child was not dependant on the education level of the parents, or number of children in the family.

Most commonly, axillary temperature was measured by using either alcohol or mercury-in-glass thermometers, from which the later was more popular. Some parents used electronic thermometers to measure the temperature on the forehead or behind the ear, but generally they were not trusted as much as the axillary thermometers:

Interview No. 10: "We have a digital thermometer to check the temperature on the forehead. But I don't trust it very much. That is why I sometimes recheck it with a mercury thermometer."

Fever management practices. Ibuprofen and Paracetamol were used by almost all the parents to reduce the temperature in their child. There seemed to be no preference to either one of these. The parents generally followed the instructions on the packaging as well as those given by their doctors. None of the parents gave both drugs simultaneously, and 4-to-6-hour breaks between medication were almost always observed. If one of the antipyretic agents seemed to be ineffective and the temperature rose before 4 to 6 hours, the other agent was used.

Eighteen respondents gave medication when the temperature of the child was between 38 and $38.4{ }^{\circ} \mathrm{C}$, and nine parents gave it when the temperature was between 38.5 and $38.9{ }^{\circ} \mathrm{C}$. Only two parents allowed the temperature to rise above $39^{\circ} \mathrm{C}$. There were five parents who administered antipyretics when the temperature was just 37.2 to 37.9 degrees high.
Interview No. 4: "Usually I give Paracetamol, if the temperature is very high, also at night, so that he would sleep better. Even if the temperature is just $37.5^{\circ} \mathrm{C}$. During the day if the temperature is higher than $38^{\circ} \mathrm{C} . . . "$

Alternative ways to reduce body temperature were used by most of the participants, which included undressing the child, application with wet towel or cloth, rubbing with alcohol, lemon water, or diluted vinegar, and cold bath.

Interview No. 5: "Wet towels on the forehead, on the belly, groins, and under knees. Rub with lemon water. I know that rubbing with alcohol or diluted vinegar is not allowed."

Interview No. 9: "I undress my child and then rub him with diluted vinegar."

Interview No. 12: "I apply a wet cloth (from cold water) on the forehead and the right side of the tummy. Some are helped by rubbing vodka on the skin."

Only one respondent saw these methods as unacceptable and only relied on medication. One parent used homeopathic medicine along with antipyretics.

Help-seeking behaviour. When needing advice on how to manage the child's illness, most parents first turned to their family doctors. If the family doctors were unavailable, some consulted the out-of-hours family doctor call centre, but some parents admitted they would skip the family doctor and go to the hospital as it was more convenient:

Interview No. 8: "At the beginning, we try to deal with it on our own. If we can't, we go to the hospital. We always have to wait for the visit to our family doctor, like four days for an appointment. We could go during the "acute hour", but then there are many sick children there and my child might catch something new..."

Some parents would consult their family members, friends, and acquaintances with medical education for advice before seeking help at their dedicated family doctor:

Interview No. 1: "Usually I see what I can do myself, I've got some experience. Then my wife would call her mother, to get advice from her point of view. The family doctor won't tell anything new..."

Interview No. 27: "At first I would seek the advice of my relatives who have some connection with medicine. We have a very good homeopathy specialist, sometimes we turn to him. Our family doctor would be the last one to consult, in my opinion that's just paperwork."

The reasons for seeking medical help were similar to the features that caused anxiety in the parents, which were high fever, behavioural changes, severe cough, and other sighs, such as changes in skin colour, vomiting, blood in stool, etc. Many parents sought help when they found it hard to reduce the temperature of the child. 
Interview No. 15: "[we seek help] when the child has high temperature that won't get down. When the child has difficulty breathing, weak, changed behaviour that does not improve after giving medication."

The amount of time the parents chose to wait before consulting a medic varied amongst the participants. A few would consult a doctor straight away:

Interview No. 13: "If my child has temperature, I call the doctor straight away. I try to do that as soon as I can. He needs to come and take a look. He sees what I can't see!"

Most parents would wait for a number of days and then decide if they need medical help from a doctor:

Interview No. 22: "If the temperature is under control, I usually wait for two to three days..."

While some felt very confident and would wait for longer:

Interview No. 27: "Actually I am quite a tough mother, in my opinion. 38 to $38.5{ }^{\circ} \mathrm{C}$ is nothing, I think. I would not consult a doctor for at least 3 to 5 days. I have gathered quite a lot of information, if something is not typical, then I would seek help..."

The parents who admitted seeking help early $(n=5)$ all had higher education, two were parents of one child, others had multiple children. Those who waited for longer were also mostly with higher education and were parents of one or multiple children. The age of the parents also did not differ significantly between these groups.

Expectations from healthcare personnel. The general expectations from the medical personnel were usually the same by all parents, which were: accurate diagnosis, rapid medical help and stabilisation of the condition of the child, prescription of medication that would help. None of the parents expected prescription of antibiotics regardless of diagnosis, one parent expressed dissatisfaction when she felt her doctor prescribed antibiotics just because she felt the doctor didn't know what to do. Six parents emphasised the necessity of performing blood tests and other tests to confirm the diagnosis:

Interview No. 22: "I want to know the diagnosis, what we are treating my child for. But blood tests must also be taken. The same goes to the family doctor, because, of course, full diagnostics will be performed in the hospital, all blood tests will be taken."

Interview No. 24: "If I'm in a hospital, I want investigations, blood tests [for my child], to be $100 \%$ sure that she is going to be ok."

Three parents emphasised the need for intravenous fluids as they believed it would help to reduce fever and improve the condition of the child.

Meeting the emotional and information needs of the parents was emphasised as equally important to meeting the child's medical needs. Parents wanted to know the precise diagnosis, to understand why the child had the symptoms they had, how to manage their child's illness at home, and what to look for to decide if the condition has become more serious.

Interview No. 12: "Our family doctor explains things very well. She gives logical explanations, and even draws schemes if necessary. I am very satisfied."

Interview No. 14: "If they tell me the diagnosis, they have my trust. But not that it's just a virus, that doesn't calm me down at all..."

Parents expressed the need for the doctor to provide emotional support, to show empathy and understand their concerns, and take their opinion into account. The respondents exhibited appreciation when the doctor had provided that, but disapproval when their emotional needs were not met:

Interview No. 32: "I expect not only management of the consequences, but also insight in the depth of the problem. Emotional support, to calm me down. I haven't exactly cried, but sometimes my hands were shaking when I have been very anxious... for somebody to come and tell me that everything is going to be all right..."

Interview No. 25: "In that moment I am hurting for my child, I feel his pain. I want the doctor to understand me, to see my child as their own..."

One parent shared a previous experience when she was concerned for the child, but her concerns were not paid enough attention to:

Interview No. 17: "Once my eldest daughter had cough, her face was grey, and it was difficult for her to breathe. I called the ambulance, they told me it's nothing, but I said: I feel that it is very difficult for her to breathe. We came to the hospital, and it turned out she had bilateral pneumonia, we spent three weeks there..."

\section{DISCUSSION}

This study showed that the parents had variable knowledge on proper evaluation and management of fever. Although some parents saw mild fever as beneficial to fighting the infection, the general opinion was that high fever is very dangerous to the child. Similarly to the findings of an Australian qualitative study, some parents who were informed that fever is a normal response of the body to infection and not harmful to the body, still expressed concerns that contradicted their knowledge and were reluctant to let the fever rise too high (Walsh et al., 2007).

The misconceptions about the effects of fever expressed by the study population, which were seizures, injury to the brain, kidneys, lungs, other organs, and even death, were generally the same as identified in other studies (Schmitt, 1980; Crocetti et al., 2001). Many parents in our study believed these harmful consequences may be attributed to fever as low as $38{ }^{\circ} \mathrm{C}$, which is quite low compared to other 
studies (Crocetti et al., 2001; Poirier et al., 2010). Our study did not reveal any significant differences in the opinions regarding fever between people with or without higher education, which contradicts the findings of one study (Poirier et al., 2010).

Despite having misconceptions about fever, some parents showed increasing concern over signs that have been associated with high or intermediate risk for serious illness, which were dehydration, fatigue, rapid breathing, cyanosis, seizures, pain, and swelling of an extremity (Van den Bruel et al., 2010; Davis, 2013). This, together with the case shown above in interview No. 17, shows that parental concern, although may be facilitated by fever phobia, should still be taken into account when evaluating a child's condition.

Many studies showed that fever phobia led to overly aggressive management practices, including frequent assessment of body temperature, and uncontrolled administration of antipyretics (Schmitt, 1980; Crocetti et al., 2001; Poirier et al., 2010). In our study as well there were parents who checked their child's temperature as often as once in 10 to $15 \mathrm{~min}$ utes. No parents, however, admitted to waking their child to measure temperature or give antipyretics. One parent, however, confessed of giving antipyretics prophylactically before sleep (interview No. 4). Parents preferred measuring axillary temperature over using electronic thermometers, which agrees with the guidelines of National Institute for Clinical Excellence (NICE). However, some used mercuryin-glass thermometers, the sale of which has been banned in the European Union since 2009.

The guidelines created by American Academy of Pediatrics and the National Institute for Clinical Excellence (NICE) recommend to evaluate the child's overall condition and give antipyretics only if the child is in distress or feels discomfort (Sullivan and Farrar, 2011; Davis, 2013). Despite these recommendations, more than half of the parents gave antipyretics as soon as the temperature reached 38 degrees, and five parents gave medication at even lower temperatures. Most parents used antipyretics, either Ibuprofen or Paracetamol, as the first line of treatment for fever; no parent gave them both simultaneously. The majority of respondents admitted to using other ways of reducing fever such as applications of cold towels, cold bath, rubbing with alcohol, etc, although these practices are not recommended at all (Davis, 2013).

The expectations from the healthcare personnel revealed by the respondents were similar to the findings of other studies (Kai, 1996a; Enarson et al., 2012), and showed that providing medical care and meeting parental informational and emotional needs were equally important to them. There was no pressure to prescribe antibiotics as described elsewhere (Kai, 1996b; Halls et al., 2017); instead some parents felt that blood tests were necessary for establishment of accurate diagnosis, and some other parents wanted intravenous fluids due to their perceived benefits. Overall, the prevailing beliefs about fever and the resulting management practices showed that there is a need for proactive parental education programmes to clarify the misconceptions about fever and provide information on how to evaluate the condition of their child, when to give antipyretics, and when the intervention of medical professionals is necessary.

There are several proposed strategies on how to educate parents about febrile illness in children. For example, in one Canadian study parents were educated via presentation on several health issues displayed on screens while they were waiting to be seen by a doctor in the emergency department. The results showed that only $33.7 \%$ of parents had watched the whole presentation until the end, and the overall knowledge of the parents did not improve (Reid et al., 2017). In comparison, in another study in Taiwan, parents were divided into experimental and control groups. The experimental group received simulation-based education with fever education brochures, while the control group only received the brochure. As a result, the parental fever knowledge became significantly better in the experimental group (Chang et al., 2016). It should be the goal of every medical practice to find a way how to improve the parental education process. Understanding the reasons for parental concern and realising their expectations could bring healthcare professionals one step closer to a successful dialogue with the parents.

This study, as all qualitative interview studies with convenience sampling, is subject to selection bias. The fact that most of the study population had higher education, and there was marked prevalence of interviewed mothers over fathers, could indicate that the study sample may not be representative of the whole population. However, as data saturation was reached and confirmed, we believe that all significant information has been considered in this study.

\section{CONCLUSION}

The results of this study show that parents have many unfounded misconceptions of fever, which lead to frequent administration of antipyretics. Meeting the educational and emotional needs of the parents is equally important for the healthcare professionals as providing adequate medical care for the child. Parental education initiatives must be organised in order to improve parental knowledge of fever and its management in children.

\section{ACKNOWLEDGEMENTS}

This study was part of the State Research Programme "Biomedicine", Project No. 5.6.2. "Research on acute and chronic diseases in children of wide age range to develop diagnostic and therapeutic algorithms to reduce mortality, prolong survival and improve quality of life".

\section{REFERENCES}

Al-Eissa, Y. A., Al-Zamil, F. A., Al-Sanie, A. M., Al-Salloum, A. A., Al-Tuwaijri, H. M., Al-Abdali, N. M., Al-Azzam, S. A. (2000). Home management of fever in children: Rational or ritual? Int. J. Clin. Pract., 54 (3), 138-142. 
Aronoff, D. M., Neilson, E. G. (2001). Antipyretics: Mechanisms of action and clinical use in fever suppression. Amer. J. Med., 111 (4), $304-315$.

Blumenthal, I. (1998). What parents think of fever. Family Practice, 15 (6), 513-518.

Braun, V., Clarke, V. (2006). Using thematic analysis in psychology. Qual. Res. Psychol., 3 (2), 77-101.

Caspe, W. B., Nucci, A. T., Cho, S. (1989). Extreme hyperpyrexia in childhood: Presentation similar to hemorrhagic shock and encephalopathy. Clin. Pediatr., 28 (2), 76-80.

Chang, L.-C., Lee, P.-I., Guo, N.-W., Huang, M.-C. (2016). Effectiveness of simulation-based education on childhood fever management by Taiwanese parents. Pediatr. Neonatol., 57 (6), 467-473.

Creswell, J. W., Poth, C. N. (2018). Qualitative Inquiry and Research Design: Choosing Among Five Approaches. 4th edn. SAGE, Los Angeles, CA. 488 pp.

Crocetti, M., Moghbeli, N., Serwint, J. (2001). Fever phobia revisited: Have parental misconceptions about fever changed in 20 years? Pediatrics, 107 (6), 1241-1246.

Davis, T. (2013). NICE guideline: Feverish illness in children — assessment and initial management in children younger than 5 years. Arch. Dis. Childhood., 98 (6), 232.

Enarson, M. C., Ali, S., Vandermeer, B., Wright, R. B., Klassen, T. P., Spiers, J. A. (2012). Beliefs and expectations of Canadian parents who bring febrile children for medical care. Pediatrics, 130 (4), e905-e912.

Francis, J. J., Johnston, M., Robertson, C., Glidewell, L., Entwistle, V., Eccles, M. P., Grimshaw, J. M. (2010). What is an adequate sample size? Operationalising data saturation for theory-based interview studies. Psychol. Health, 25 (10), 1229-1245.

Goodman, E. L., Knochel, J. P. (1991). Heat stroke and other forms of hyperthermia. Fever: Basic Mechanisms and Management. Raven Press, New York, 267-287.

Halls, A., van't Hoff, C., Little, P., Verheij, T., Leydon, G. M. (2017). Qualitative interview study of parents' perspectives, concerns and experiences of the management of lower respiratory tract infections in children in primary care. BMJ Open, 7 (9), e015701.

Hay, A. D., Heron, J., Ness, A. (2005). The prevalence of symptoms and consultations in pre-school children in the Avon Longitudinal Study of Parents and Children (ALSPAC): A prospective cohort study. Family Pract., 22 (4), 367-374

Heron, I., Berg, K. (1978). The actions of interferon are potentiated at elevated temperature. Nature, 274 (5670), 508-510.

Kai, J. (1996a). Parents' difficulties and information needs in coping with acute illness in preschool children: A qualitative study. BMJ, 313 (7063), 987.

Received 7 November 2018

Accepted in the final form 11 February 2019
Kai, J. (1996b). What worries parents when their preschool children are acutely ill, and why: a qualitative study. BMJ, 313 (7063), 983-986.

Mackowiak, P. A. (1998). Concepts of fever. Arch. Int. Med., 158 (17), 1870-1881.

McErlean, M. A., Bartfield, J. M., Kennedy, D. A., Gilman, E. A., Stram, R L., Raccio-robak, N. (2001). Home antipyretic use in children brought to the emergency department. Pediatr. Emerg. Care, 17 (4), 249-251.

Nijman, R. G., Vergouwe, Y., Thompson, M., van Veen, M., van Meurs, A H. J., van der Lei, J., Oostenbrink, R. (2013). Clinical prediction model to aid emergency doctors managing febrile children at risk of serious bacterial infections: Diagnostic study. BMJ, 346 (16), f1706.

Poirier, M. P., Collins, E. P., McGuire, E. (2010). Fever phobia: A survey of caregivers of children seen in a pediatric emergency department. Clin. Pediatr., 49 (6), 530-534.

Reid, S., Neto, G., Tse, S., Farion, K. J., Marvizi, A., Smith, L., Clarkin, C., Rhode, Moreau, K. (2017). Education in the waiting room: Description of a pediatric emergency department educational initiative. Pediatr. Emerg. Care, 33 (10), e87-e91.

Roberts Jr, N. J. (1991). The immunological consequences of fever. Fever: Basic Mechanisms and Management. Raven Press, New York. 125 pp.

Ron, Y., Dougherty, J. P., Duff, G. W., Gershon, R. K. (1984). The effect of febrile temperatures on biologic actions of interferons: Abrogation of suppression of delayed-type hypersensitivity and antibody production. $J$. Immunol., 133 (4), 2037-2042.

Schmitt, B. D. (1980). Fever phobia: Misconceptions of parents about fevers. Amer. J. Dis., Child., 134 (2), 176-181.

Simon, H. B. (1993). Hyperthermia. New Engl. J. Med., 329 (7), 483-487

Singhi, S., Padmini, P., Sood, V. (1991). Urban parents' understanding of fever in children: Its dangers, and treatment practices. Indian Pediatr., 28 (5), 501-505.

Srivastava, P. (2002). Roles of heat-shock proteins in innate and adaptive immunity. Nature Rev. Immunol., 2 (3), 185-194.

Starks, H., Brown Trinidad, S. (2007). Choose your method: A comparison of phenomenology, discourse analysis, and grounded theory. Qual. Health Res., 17 (10), 1372-1380.

Sullivan, J. E., Farrar, H. C. (2011). Fever and antipyretic use in children. Pediatrics, 127 (3), 580-587.

Van den Bruel, A., Haj-Hassan, T., Thompson, M., Buntinx, F., Mant, D. (2010). Diagnostic value of clinical features at presentation to identify serious infection in children in developed countries: A systematic review. Lancet, 375 (9717), 834-845.

Walsh, A., Edwards, H., Fraser, J. (2007). Influences on parents' fever management: beliefs, experiences and information sources. J. Clin. Nursing, 16 (12), 2331-2340

\section{RŪPĒJOTIES PAR BĒRNU AR DRUDZI: KVALITATĪVS PĒTĪJUMS AR VECĀKU INTERVIJĀM}

Pētîjuma mērḳis bija izpētìt bērnu saslimšanu ar drudzi vecāku uztverē, biežākos paradumus bērnu ar drudzi ārstēšanā un aprūpē, kā arī vecāku gaidas no medicīnas personāla, rūpējoties par bērnu ar drudzi. Pētījumā tika iekḷauti to bērnu vecāki, kuri bija vērsušies Bērnu klīniskās universitātes slimnīcas Neatliekamās palīdzības un Observācijas nodaḷā sakarā ar drudzi bērnam. Dati tika ievākti daḷēji strukturētu interviju veidā. Interviju transkripti tika analizēti ar induktīvās tematiskās analīzes metodi. Pētījumam tika analizētas trīsdesmit četras vecāku intervijas. To saturā dominēja sešas tēmas: pazīmes, kuras vecākos radīja satraukumu; uzskati par drudzi; bērna temperatūras izvērtēšana un monitorēšana; paradumi drudža mazināšanā; palīdzības meklēšanas paradumi; gaidas no medicīnas personāla. Daudzi vecāki uzskatīja, ka drudzis ir potenciāli bīstams bērna nervu sistēmai, nierēm, smadzenēm, plaušām un citiem orgāniem, pat izraisot nāvi. Uzskati par drudža bīstamību veicināja biežu bērna temperatūras mērīšanu un antipirētiḳu lietošanu. Vecāku vajadzība pēc izskaidrojuma bērna saslimšanai un emocionālā atbalsta tika uzskatīta par vienlīdz svarīgu ar bērna medicīnisko aprūpi. Vecāku uzskatos par drudzi dominēja "drudža fobija". Uzskati par drudža bīstamību veicināja pārmērīgas rūpes drudža mazināšanai. Lai uzlabotu vecāku zināšanas par drudzi un pareizu bērnu ar drudzi aprūpi, jāveic mērḳtiecīgs izglītojošais darbs. 